E3S Web of Conferences 1, 17001 (2013)

DOI: $10.1051 / \mathrm{e} 3$ sconf/20130117001

(c) Owned by the authors, published by EDP Sciences, 2013

\title{
CARIBIC observations of gaseous mercury in the upper troposphere and lower stratosphere
}

F. Slemr ${ }^{1}$, R. Ebinghaus ${ }^{2}$, A. Weigelt ${ }^{2}$, H. H. Kock ${ }^{2}$, C. A. M. Brenninkmeijer ${ }^{1}$, T. Schuck ${ }^{1}$, M. Hermann ${ }^{3}$, A. Zahn ${ }^{4}$, P. van Velthoven ${ }^{5}$, B. Martinsson ${ }^{6}$ and H. Ziereis ${ }^{7}$

${ }^{1}$ Max-Planck-Institut für Chemie, P.O.Box 3060, D-55020 Mainz, GERMANY, franz.slemr@mpic.de, carl.brenninkmeijer@mpic.de, tanja.schuck@mpic.de

${ }^{2}$ Helmholtz-Zentrum Geesthacht, Institute of Coastal Research, Max-Planck-Strasse, D-21502 Geesthacht, GERMANY, ralf.ebinghaus@hzg.de,andreas.weigelt@hzg.de,hans.kock@hzg.de

${ }^{3}$ Leibniz-Institut für Troposphärenforschung (IFT), Permoserstrasse 15, D-04318 Leipzig, GERMANY, hermann@tropos.de

${ }^{4}$ Karlsruhe Institute of Technology (KIT), Institute of Meteorology and Climate Research (IMK), P.O.Box 3640, D-76021 Karlsruhe, GERMANY, andreas.zahn@kit.edu

${ }^{5}$ Royal Netherlands Meteorological Institute (KNMI), P.O.Box 201, NL-3730 AE, de Bilt, NETHERLANDS, velthove@knmi.nl

${ }^{6}$ University of Lund, Division of Nuclear Physics, P.O.Box 118, S-22100 Lund, SWEDEN, bengt.martinsson@nuclear.lu.se

${ }^{7}$ Deutsches Zentrum für Luft- und Raumfahrt (DLR), Institut für Physik der Atmosphäre, D-82230 Wessling, GERMANY,helmut.ziereis@dlr.de

\begin{abstract}
A unique set of gaseous mercury measurements in the upper troposphere and lower stratosphere (UT/LS) has been obtained during the monthly CARIBIC (www.caribic-atmospheric.com) flights since May 2005. The passenger Airbus 340-600 of Lufthansa covered routes to the Far East, North America, India, and the southern hemisphere. The accompanying measurements of $\mathrm{CO}, \mathrm{O}_{3}, \mathrm{NOy}, \mathrm{H}_{2} \mathrm{O}$, aerosols, halocarbons, hydrocarbons, greenhouse gases, and several other parameters as well as backward trajectories enable a detailed analysis of these measurements. Speciation tests have shown that the CARIBIC measurements represent a good approximation of total gaseous mercury (TGM) concentrations. Above the tropopause TGM always decrease with increasing potential vorticity $(\mathrm{PV})$ and $\mathrm{O}_{3}$ which implies its conversion to particle bound mercury. The observation of the lowest TGM concentrations at the highest particle concentrations in the stratosphere provides further evidence for such conversion. We will show how a seasonally dependent conversion rate could be derived using concomitantly measured $\mathrm{SF}_{6}$ mixing ratios as a timer. Tropospheric mercury data suggest the existence of a decreasing trend in the northern hemisphere whose size is comparable with the trend derived from long-term measurements by ship cruises, at Cape Point (South Africa) and Mace Head (Ireland).
\end{abstract}

Key words: Heavy metals, mercury, distribution, troposphere, stratosphere, measurement, trend.

\section{Introduction}

Despite more than 25 years of research on atmospheric mercury the information about the distribution in the troposphere and stratosphere is sparse. It was the introduction of the automated Tekran instrument which enabled the first highly resolved aircraft measurements of spatial distribution of mercury in the atmosphere at the beginning of this century (Ebinghaus and Slemr, 2000, Banic et al., 2003; Friedli et al., 2003). Since then about a dozen of other papers on airborne mercury measurements have been published as reviewed by Sprovieri et al. (2010). Almost all of these measurements have been made as campaigns with specific objectives and are thus limited in region and time. Consequently, they provide only regional snapshots of the mercury distribution in the atmosphere. Monthly intercontinental CARIBIC flights made since May 2005 are the only exception. The results until May 2007 were published by Ebinghaus et al. (2007) and Slemr et al. (2009). In this 
paper we will present selected findings from the regular CARIBIC flights made since then.

\section{Materials and Methods}

The new CARIBIC system consisting of a permamently mounted inlet and a monthly installed instrumented container is described in detail by Brenninkmeijer et al. (2007). The container holds automated analyzers for gaseous mercury, $\mathrm{CO}, \mathrm{O}_{3}, \mathrm{NO}, \mathrm{NOy}, \mathrm{CO}_{2}$, total and gaseous water vapor, oxygenated organic compounds, and fine particles (three counters for particles with diameters $>4 \mathrm{~nm},>12 \mathrm{~nm}$, and $>18 \mathrm{~nm}$ ), as well as an optical particle counter for particles with diameters $>150 \mathrm{~nm}$. Additionally, 28 whole air samples and 16 aerosol samples have been taken during a typical monthly sequence of 4 intercontinental flights with a total flight time of about $40 \mathrm{~h}$. After the flight sequence the air samples are analyzed in laboratory for greenhouse gases (Schuck et al. 2009), hydrocarbons (Baker et al., 2010), and halocarbons (Oram et al., 2012). The aerosol samples are analyzed for their elemental composition and their morphology (Nguyen et al., 2008). In 2010 the instrumentation was expanded by an additional whole air sampler with a capacity of 90 samples, and instruments for continuous measurements of water isotopologues and $\mathrm{CH}_{4}$.

Mercury is measured by a Tekran analyzer modified for the automatic operation in the container. The inlet tubing is all PFA lined and consists of high volume flow circular tubing with a manifold whose temperature is kept at $40^{\circ} \mathrm{C}$ and a short PFA connection to the instrument at internal container temperature of about $30^{\circ} \mathrm{C}$. It was designed according to recommendations by Neuman et al. (1999) for sampling of atmospheric $\mathrm{HNO}_{3}$, one of the compounds that are the most difficult to measure because of its tendency to stick to surfaces. For operation at cruising altitudes around $10 \mathrm{~km}$ the air sample is compressed by a diaphragm pump from ambient pressure to abou $500 \mathrm{hPa}$ needed to operate the Tekran instrument with its internal pump. The pump was tested and found to produce neither mercury contamination nor memory effects. The instrument is protected by a $0.2 \mu \mathrm{m}$ PTFE pre-filter. Because of limitation on number of high pressure cylinders in the container, the instrument was operated initially with a $\mathrm{CO}_{2} / \mathrm{Ar}$ mixture instead pure $\mathrm{Ar}$ which led to a substantial reduction of sensitivity. Consequently, the initial sampling interval was $15 \mathrm{~min}$, which was then reduced to $10 \mathrm{~min}$. With cartridges removing $\mathrm{CO}_{2}$ the sampling interval was later reduced to 5 min but now we operate the instrument with $10 \mathrm{~min}$ sampling interval to reach a detection limit and a precision of $\sim 0.05 \mathrm{ng} \mathrm{m}^{-3}$. The results are corrected for the pressure in the instrument (Slemr et al., 2009) and are given in $\mathrm{ng} \mathrm{m}^{-3}$ (STP) with standard temperature of 273.14 $\mathrm{K}$ and pressure of $1013.25 \mathrm{hPa}$.

Since May 2005 almost 300 intercontinental flights were made representing some $2500 \mathrm{~h}$ of mercury measurements in the upper troposhere and lower stratosphere (UT/LS).

\section{Results and Discussion}

In this section we will present and discuss briefly three major results: the speciation of the measured mercury, the behavior of mercury in the lower stratosphere, and the trend of tropospheric mercury concentrations.

Speciation experiments have been made initially with soda lime and later with $\mathrm{KCl}$ coated quartz sand traps in one of the two channels of the instrument during the regular monthly flights. The experiments demonstrated clearly that reactive gaseous mercury (RGM) passes through the inlet system consisting of the manifold, the connection tubing, the diaphragm pump, and the PTFE pre-filter. Unfortunately, quantitative measurements of the inlet RGM transmission during the flight are not feasible because of lack of suitable airborne RGM calibration sources. Alternatively, tests on ground are not representative for the conditions at flight altitudes. But the RGM transmission is consistent with findings of Temme et al. (2003) who reported quantitative RGM transmission of PFA tubing at low temperature and dry air conditions encountered in Antarctica. These conditions are similar to conditions in UT/LS. Although we cannot specify quantitatively the RGM transmission of our inlet system, we know it is high and, consequently, deem our mercury measurements to be a close approximation of total gaseous mercury (TGM). Below we present them as such. We are waiting for in-flight intercomparison with a speciation-capable measurement system to determine the RGM transmission of our system.

In the lower stratosphere TGM concentration always decreases with increasing $\mathrm{PV}$ and $\mathrm{O}_{3}$. In this behavior it is similar to all trace species with ground sources and stratospheric sinks such as $\mathrm{CO}$ and $\mathrm{CH}_{4}$. Opposite to such species, mercury as an element can only be transformed to other mercury species which escape detection by our instrument - i.e. to particle bound mercury. The existence of high particulate mercury concentrations and their coincidence with high particulate bromine concentrations in the lower stratosphere has been reported by Murphy et al. (1998, 2006). We tried to quantify mercury on the aerosol samples collected during the CARIBIC flights but failed because the semi-volatile mercury compounds on the particles are pumped away during the analysis in vacuum by proton-induced $\mathrm{x}$-ray emission. This failure suggests that TGM is more likely to be converted to semi-volatile mercury halogenides (e.g. $\mathrm{HgBr}_{2}, \mathrm{HgOHBr}$, $\mathrm{HgCl}_{2}$ ) than to much less volatile $\mathrm{HgO}$. The link of decreasing TGM in the lower stratosphere is further supported by the relation of TGM and particle concentration in the deep stratosphere: the highest TGM is found in air masses with lowest particle concentrations and vice versa.

The transformation rate of TGM to particle bound mercury can be calculated using $\mathrm{SF}_{6}$ as a timer. $\mathrm{SF}_{6}$ is a very long-lived tracer whose concentration increases by about $0.230 \mathrm{ppt} \mathrm{yr}^{-1}$. Correlations of TGM with $\mathrm{SF}_{6}$ suggest a seasonally dependent TGM conversion rate of about $0.43 \mathrm{ng} \mathrm{m}^{-3} \mathrm{yr}^{-1}$ resulting in a stratospheric TGM lifetime of about $2 \mathrm{yr}$. This lifetime is longer than several weeks claimed recently by Lyman and Jaffe (2012) but is 
closer to $1 \mathrm{yr}$ estimated by Holmes et al. (2010) using GEOS model with bromine oxidation chemistry.

Long-term regular CARIBIC mercury observations enable us also to investigate trends. For this we selected only tropospheric measurements (i.e. PV $<1.5 \mathrm{PVU}$ ) in the northern hemisphere $\left(>15^{\circ} \mathrm{N}\right)$ to avoid large gradients on the tropopause and between the hemispheres. The result is shown in Fig. 1. The decreasing trend is according to Man-Kendall test significant at $97.1 \%$ level and Sen's slope estimate yields a trend of $-0.036(-0.076$ to +0.001 at $95 \%$ significance level) $\mathrm{ng} \mathrm{m}^{-3} \mathrm{yr}^{-1}$. This trend confirms the worldwide extension of the trends of $-0.035 \pm 0.006$ and $-0.024 \pm 0.005 \mathrm{ng} \mathrm{m}^{-3} \mathrm{yr}^{-1}$ in southern and northern hemispheres, respectively, derived by Slemr et al. (2011) from mercury observations during ship cruises, at Cape Point, South Africa, and Mace Head, Ireland.

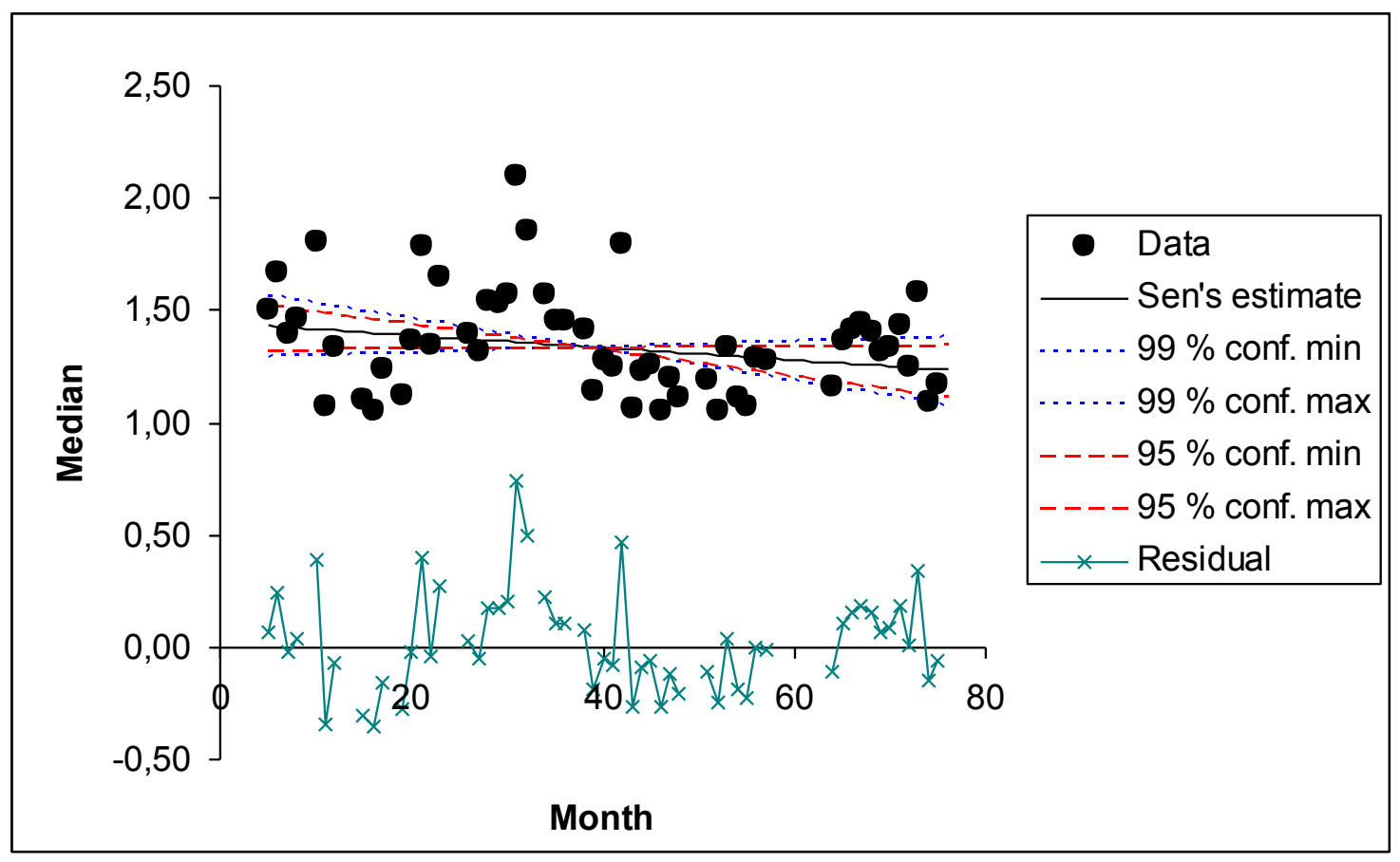

Fig. 1. Monthly averages of TGM concentrations in the troposphere (PV $<1.5 \mathrm{PVU})$ north of $15^{\circ} \mathrm{N}$ from May 2005 to April 2011 with Sen's slope estimate.

\section{Conclusion}

Ongoing regular monthly mercury observations onboard CARIBIC passenger aircraft since May 2005 provide unique information about the distribution of mercury in the UT/LS region, its seasonal variation and long-term development. Information about mercury sources such as biomass burning has also been obtained (Ebinghaus et al. 2007). They also provide data which can and are used to verify the global mercury models.

\section{Acknowledgements}

The authors thank for the financial support from European Commission within the GMOS (Global Mercury Observation System, www.gmos.eu) project (FP7-ENV-2010), from Fraport AG, and Max-Planck-Society.

\section{References}

Baker, A.K., Slemr, F., Brenninkmeijer, C.A.M. Analysis of non-methane hydrocarbons in air samples collected aboard the CARIBIC passenger aircraft, Atmos. Meas. Tech. 3, 311-321, 2010.

Banic, C.M., Beauchamp, S.T., Tordon, R.J., Schroeder, W.H., Steffen, A., Anlauf, K.A., Wong, K.H.T. Vertical distribution of gaseous elemental mercury in Canada, J. Geophys. Res. 108, D9, 4264, doi:10.1029JD002116, 2003.

Brenninkmeijer, C.A.M., Crutzen, P., et al. Civil aircraft for the regular investigation of the atmosphere based on instrumented container. The new CARIBIC system, Atmos. Chem. Phys. 7, 4953-4976, 2007.

Ebinghaus, R., Slemr, F. Aircraft measurements of atmospheric mercury over southern and eastern Germany, Atmos. Environ. 34, 895-903, 2000.

Ebinghaus, R., Slemr, F., Brenninkmeijer, C.A.M., van Velthoven, P., Zahn, A., Hermann, M., O'Sullivan, D.A., Oram, D.E. Emissions of gaseous mercury from biomass burning in South America in 2005 observed during CARIBIC flights, Geophys. Res. Lett. 34, L08813, doi:10.1029/2006GL028866, 2007.

Friedli, H.R., Radke, L.F., Lu, J.Y., Banic, C.M., Leaitch, W.R., MacPherson, J.I. Mercury emissions from 
burning of biomass from temperate North American forests: laboratory and airborne measurements, Atmos. Environ, 37, 253-267, 2003.

Holmes, C.D., Jacob, D.J., Corbitt, E.S., Mao, J., Yang, X., Talbot, R., Slemr, F. Global atmospheric model for mercury including oxidation by bromine atoms, Atmos. Chem.. Phys. 10, 12037-12057, 2010.

Lyman, S.N., Jaffe, D.A. Formation and fate of oxidized mercury in the upper troposphere and lower stratosphere, Nature Geoscience, doi:10.1038/NGEO1353, 2011.

Murphy, D.M., Thomson, D.S., Mahoney, M.J. In situ measurements of organics, meteoritic material, mercury, and other elements in aerosols at 5 to 19 kilometers, Science 282, 1664-1669, 1998.

Murphy, D.M., Hudson, P.K., Thomson, D.S., Sheridan, P.J., Wilson, J.C. Observations of mercury-containing aerosols, Environ. Sci. Technol. 40, 3163-3167, 2006.

Neuman, J.A., Huey, L.G., Ryerson, T.B., Fahey, D.W. Study of inlet materials for sampling atmospheric nitric acid, Environ. Sci. Technol. 33, 1133-1136, 1999.

Nguyen, H.N., Martinsson, B.G., Wagner, J.B., Carlemalm, E., Ebert, M., Weinbruch, S., Brenninkmeijer, C.A.M., Heintzenberg, J., Hermann, M., Schuck, T., van Velthoven, P.F.J., Zahn, A. Chemical composition and morphology of individual aerosol particles from CARIBIC flight at $10 \mathrm{~km}$ altitude between $50^{\circ} \mathrm{N}$ and $30^{\circ} \mathrm{S}$, J. Geophys. Res. 113, D23209, doi:10.1029/2008JD009956,
2008.

Oram, D.E., Mani, F.S., Laube, J.C., Newland, M.J., Reeves, C.E., Sturges, W.T., Penkett, S.A., Brenninkmeijer, C.A.M., Röckmann, T., Fraser, P.J., Long-term tropospheric trend of octafluorocyclobutane $\left(\mathrm{c}-\mathrm{C}_{4} \mathrm{~F}_{8}\right.$ or PCF-318), Atmos, Chem. Phys. 12, 261-269, 2012.

Schuck, T.J., Brenninkmeijer, C.A.M., Slemr, F., Yueref-Remy, I., Zahn, A. Greenhouse gas analysis of air samples collected onboard the CARIBIC passenger aircraft, Atmos. Meas. Tech. 2, 449-464, 2009.

Slemr, F., Ebinghaus, R., Brenninkmeijer, C.A.M., Hermann, M., Kock, H.H., Martinsson, B.G., Schuck, T., Sprung, D., van Velthoven, P., Zahn, A., Ziereis, H. Gaseous mercury distribution in the upper troposphere and lower stratosphere observed onboard the CARIBIC passenger aircraft, Atmos. Chem. Phys. 9, 1957-1969, 2009.

Slemr, F., Brunke, E.-G., Ebinghaus, R., Kuss, J. Worldwide trend of atmospheric mercury since 1995, Atmos. Chem. Phys. 11, 4779-4787, 2011.

Sprovieri, F., Pirrone, N., Ebinghaus, R., Kock, H., Dommergue, A. A review of worldwide atmospheric mercury measurements, Atmos. Chem. Phys. 10, 8245-8265, 2010.

Temme, C., Einax, J.W., Ebinghaus, R., Schroeder, W.H. Measurements of atmospheric mercury species at a coastal site in the Antarctic and over the South Atlantic Ocean during polar summer, Environ. Sci. Technol. 37, 22-31, 2003. 